\title{
UTERINE HEMODYNAMICS AND OVARIAN RESERVE QUALITY IN THE PREDICTION OF IN VITRO FERTILIZATION OUTCOMES
}

\author{
Rabadanova AK, $\bowtie$ Shalina RI, Gugushvili NA \\ Department of Obstetrics and Gynecology, Faculty of Pediatrics, \\ Pirogov Russian National Research Medical University, Moscow
}

\begin{abstract}
There are a few major factors determining the success of in vitro fertilization (IVF), including the potential of embryos to implant and the receptivity of the endometrium, which, in turn, are directly dependent on the ovarian reserve, i.e. the quality and quantity of oocytes. Diminished ovarian reserve can be inferred from reduced blood flow to the uterus on Doppler sonography. Based on the results of 3D power Doppler imaging of uterine blood flow on the day of ET and Virtual Organ Computer-aided AnaLysis (VOCAL), we attempted to predict the outcomes of IVF and embryo transfer (ET) in 56 female patients with different ovarian reserves. Blood flow was measured in the uterus, subendometrial region and endometrium, and IVF cycle outcomes were subsequently assessed. We have established an association between the characteristics of uterine and subendometrial blood flow and the outcomes of IVF cycles and ET. No such association has been established for the endometrium, though. Therefore, a 3D power Doppler examination on the day of embryo transfer provides valuable information on the endometrium receptivity and can be used as a prognostic marker of IVF success.
\end{abstract}

Keywords: IVF, 3D power Doppler, diminished ovarian reserve, poor ovarian response, uterine blood flow

$\triangle$ Correspondence should be addressed: Asiyat Rabadanova

Mnevniki 23, k. 254, Moscow, 123423; asyakubataeva@gmail.com

Received: 15.03.2018 Accepted: 20.03.2018

DOI: $10.24075 /$ brsmu.2018.015

\section{ГЕМОДИНАМИКА МАТКИ И СОСТОЯНИЕ ОВАРИАЛЬНОГО РЕЗЕРВА В ОЦЕНКЕ ЭФФЕКТИВНОСТИ ЭКСТРАКОРПОРАЛЬНОГО ОПЛОДОТВОРЕНИЯ}

\author{
А. К. Рабаданова, $~ Р$. И. Шалина, Н. А. Гугушвили \\ Кафедра акушерства и гинекологии, педиатрический факультет, \\ Российский национальный исследовательский медицинский университет имени. Н. И. Пирогова
}

\begin{abstract}
Эфффективность программы экстракорпорального оплодотворения (ЭКО) зависит от ряда факторов, среди которых большое значение имеют эмбриональный и эндометриальный. Каждый из этих факторов напрямую зависит от овариального резерва, определяющего качество ооцитов и изменение допплерометрических показателей в матке, которые отражают снижение внутриматочной перфузии. Целью исследования было прогнозирование эффективности циклов ЭКО и переноса эмбрионов (ПЭ) у пациенток с различным овариальным резервом на основании определения объемногокровотокавматкевденьпереносаэмбрионаспомощью3D-УЗИсфункциейэнергетическойдопплерографии. У 56 пациенток с различным овариальным резервом произведено измерение параметров кровотока с помощью 3D-УЗИ и прикладной программы VOCAL (Virtual Organ Computer-aided AnaLysis) в матке, субэндометриальной зоне и в эндометрии в день переноса эмбриона с последующей оценкой эффективности циклов ЭКО. В ходе работы установлена зависимость между параметрами 3D-кровотока в матке и субэндометриальной зоне и эффективностью циклов ЭКО и ПЭ. При исследовании кровотока в эндометрии такая зависимость не выявлена. Таким образом, использование 3D-УЗИ с функцией энергетической допплерографии в день переноса эмбриона позволяет судить о степени выраженности рецептивности эндометрия и может быть использовао в качестве прогностического критерия для определения вероятности наступления беременности в цикле ЭКО.
\end{abstract}

Ключевые слова: экстракорпоральное оплодотворение, сниженный овариальный резерв, маточный кровоток, 3D-УЗИ с функцией энергетической допплерографии

$\triangle$ Для корреспонденции: Асият Рабаданова

ул. Мнёвники, д. 23, к. 254, г. Москва, 123423; asyakubataeva@gmail.com

Статья получена: 15.03.2018 Статья принята к печати: 20.03.2018

DOI: $10.24075 /$ vrgmu.2018.015

Today, the success of in vitro fertilization (IVF) is seen as a combination of two major factors: the ability of embryos to implant and the receptivity of the endometrium [1]. These two factors are directly dependent on the ovarian reserve of the female patient. In patients with diminished ovarian reserve the quality of oocytes tends to degrade [2] and Doppler ultrasonography reveals decreased uterine perfusion. In the study presented below we chose to focus on the endometrial blood flow as the quality of transferred embryos was good; so their ability to implant is not discussed here.

In 2013 the Russian Association of Human Reproduction (RAHR) reported that the use of cryopreserved donor eggs 
in females over 40 years of age improves the outcome of IVF cycles by as little as $4.8 \%$ [3]. The figures published in the report suggest that better IVF outcomes in patients with diminished ovarian reserve are largely determined by the receptive quality of the endometrium. In this light, the discovery of robust methods for its assessment and enhancement should receive special attention. Conveniently, three-dimensional power Doppler ultrasonography can be a perfect non-invasive tool for predicting endometrial receptivity $[4,5]$.

Proliferation and differentiation of endometrial cells is controlled by ovarian steroid hormones promoting angiogenesis [6], which plays a crucial role in stimulating endometrial growth and ensures good implantation of the embryo [7, 8]. Sufficient blood supply to the endometrial and subendometrial regions is an essential prerequisite for successful implantation.

The study conducted in 2012 [8] compared the prognostic value of $2 \mathrm{D}$ and $3 \mathrm{D}$ ultrasonography in the assessment of endometrial receptivity, which signals the opening or closure of the implantation window. The data on the endometrial blood flow obtained during the scans were compared to the findings of endometrial biopsy. It was established that 3D ultrasonography is a more accurate prognostic tool than $2 \mathrm{D}$ ultrasonography. The lack of correlation between 2D ultrasonography findings and IVF outcomes was also reported by other researchers [9].

Unfortunately, few authors have studied the uterine blood flow as a predictor of the outcomes of infertility treatment with embryo transfer in patients with different ovarian reserves, so the literature on this problem is scarce.

In our study we attempted to establish a correlation between the outcome of an IVF cycle and the findings of a 3D power Doppler examination of uterine blood flow in patients with different ovarian reserves on the day of embryo transfer.

\section{METHODS}

The study was carried out at the facilities of the Center for Family Planning and Reproductive Health (Department of Reproduction) between 2015 and 2017.

As part of the study, we conducted a prospective analysis of standard IVF cycles in 56 female patients with different ovarian reserves. The treatment included transfer of no more than 2 blastocysts on day 5 after oocyte retrieval. Based on the outcome of the IVF cycle we distributed the patients into 2 groups. The first group included 21 patients who became pregnant after IVF, and the second group consisted of 35 patients whose IVF cycle failed. Among the patients who achieved pregnancy, 13 (61.9\%) had been previously diagnosed with tuboperitoneal infertility and 8 (38.1\%) had a diminished ovarian reserve. Twenty-three (65.7\%) of all patients who did not achieve pregnancy had been diagnosed with tuboperitoneal infertility, and in 12 (34.2\%) females the ovarian reserve was diminished.

Our study was conducted in the females between 30 and 40 years of age diagnosed with diminished ovarian reserve and tuboperitoneal infertility.

Patients with ovarian neoplasms, myomas, adenomyosis, and those who had previously undergone a therapy to improve their uterine blood flow or had an infertile partner were excluded from the study.

The loss of ovarian reserve was assessed by measuring the levels of the follicle stimulating hormone (FSH) and the antiMüllerian hormone (AMH), and by counting antral follicles less than $10 \mathrm{~mm}$ in size identified during the ultrasound scan on days 2-3 of treatment. If FSH levels exceeded $8 \mathrm{IU} / \mathrm{I}$ and $\mathrm{AMH}$ levels were lower than $1 \mathrm{ng} / \mathrm{ml}$ and the number of retrieved oocytes was $<3$, then the ovarian reserve was considered diminished.

In the course of treatment, patients' ovaries were stimulated by gonadotropin-releasing hormone antagonists. Ovulation was induced by a recombinant FSH.

The starting dose of FSH (75 to 275 IU/24 hours) was individually selected for each patient depending on her age, body mass index (BMI), FSH and $\mathrm{AMH}$ levels, and ovarian response to previous treatment cycles. Follicle development was monitored by ultrasonography. Once a leading follicle had reached 18-20 mm in diameter, we introduced an ovulation trigger (human chorionic gonadotropin HCG) and 34-36 hours later performed a transvaginal puncture of follicles of $>15 \mathrm{~mm}$ in size. Oocyte retrieval, insemination, culture, ET and lutein phase support by progesterone administration in the post-transfer period were performed according to standard protocols [2].

On the day of embryo transfer the patients underwent an ultrasound examination; a 3D image of the uterus was reconstructed in a 3D power Doppler mode. The procedure was performed on Voluson 730 Expert (GE Healthcare, Austria) equipped with an endovaginal transducer (frequency range from 5 to $9 \mathrm{MHz}$ ). Because blood flow characteristics are sensitive to varying frequencies, we used the following settings: Gn of 9.0, Frq, low; Qual, norm; WMF, low1; PRF, 0.9 kHz.

The original 2D image for further $3 \mathrm{D}$ reconstruction represented the central plane of the volume of interest [10, 11]; the scan swept through the volume from one of its borders to another. The scan angle was $120^{\circ}$; the rotation step was exactly $15^{\circ}$, because otherwise the vessels located in close proximity to the uterus could have been captured into the reconstructed volume.

The contours of the endometrium and the uterus were manually delineated using the VOCAL software. Blood flow was assessed in 1) the endometrial region with the contour drawn along its basal layer and in 2) the endometrium and a 5-mm shell area around its basal layer which included the subendometrium with its basal and radial arteries [12]. Jagged contours after contouring were regarded as an error.

After the reconstruction, the volumes of the uterus, endometrium and subendometrium were computed. A few important histogram indices were also computed, including the vascularization index $(\mathrm{VI})$, which represents the percentage of blood vessels in a given tissue volume; the flow index (FI), which represents the blood volume moving through the vessels during the scan, and the vascularization-flow index (VFI), which provides information on the organ perfusion.

The data were processed in Excel 7.0 and Statistica 6.0. The parameters analyzed were compared pairwise; differences were considered significant at $p<0.05$. We also used the AUC $\mathrm{ROC}$ analysis. Generally, the higher is AUC, the better is the performance of the model. The performance scale used in our study was as follows: 0.9-1.0, excellent; 0.8-0.9, very good; 0.7-0.8, good; 0.6-0.7, fair; 0.5-0.6, poor.

\section{RESULTS}

Patients' age varied between 30 and 42 years (mean age was $34.27 \pm 3.98$ years). There were 17 patients under 35 and 39 patients between 35 and 42 years of age. The mean age of the patients who achieved pregnancy after ET (group 1) was $34.27 \pm 3.98$ years. The mean age of the patients whose IVF failed (group 2) was $36.00 \pm 3.74$ years $(p>0.05)$. Although IVF tended to fail in older patients, especially in those with diminished ovarian reserve, no significant differences were 
revealed between the groups with regard to this parameter (Table 1).

Because candidates for the infertility treatment with assisted reproductive technologies (AST) were selected very carefully, the rate of extragenital pathologies fell within the population range.

A relatively big number of patients (40\%) with diminished ovarian reserve whose IFV treatment failed had previously undergone an ovarian surgery (Table 1). Of them 5 patients $(31.2 \%)$ had received surgical treatment for cystadenomas and 11 patients (68.8\%) for endometroid cysts.

About half of our patients $(48.6 \%$, or 17 individuals with different ovarian reserves) whose IVF failed had a previous history of dilation and curettage. Of them 14 had received treatment for uterine polyps and 3 for endometrial hyperplasia In patients who achieved pregnancy after IVF endometrial pathologies were 1.7 times less frequent (Table 1).

The duration of infertility ranged from 1 to 11 years. The patients with diminished ovarian reserve had a longer history of infertility than those with normal ovarian reserve, but the difference between those two groups was insignificant (Table 1).

The majority of the patients who achieved pregnancy had been previously diagnosed with primary sterility. The same was true for 20 patients (57.1\%) whose IVF failed.

$\mathrm{FSH}$ and $\mathrm{AMH}$ levels regulating the ovarian function differed significantly between the patients with different ovarian reserves. Low AMH and high FSH were observed in the patients with diminished ovarian reserve (Table 1).

Doses of $r F S H$ administered to the patients and the number of transferred embryos did not differ significantly between the groups.

On day 5 after oocyte retrieval and before embryo transfer, the patients underwent 2D and 3D power Doppler ultrasonography.

Endometrial thickness measured on the day of embryo transfer varied from 8.0 to $14.5 \mathrm{~mm}$ in the patients who achieved pregnancy after IVF. The endometrium was the thickest $(14.5 \mathrm{~mm})$ in the patient who later gave birth to twins. In the females whose IVF failed the thickness of the endometrium varied from 7.0 to $10.6 \mathrm{~mm}$. The differences in the endometrial thickness were significant between the patients whose IVF was successful and those whose IVF was ineffective, for both good and bad ovarian reserves ( $p=0.003 ; p=0.05$ ) (Table 1).

Therefore, endometrial thickness measured on the day of embryo transfer can be a good prognostic marker of the IVF cycle outcome regardless of the quality of ovarian reserve.

The uterine volume measured by 3D Doppler varied from 31.7 to $83.3 \mathrm{~mm}^{3}$ in group 1 (successful IVF) and from 21.0 to $90.3 \mathrm{~mm}^{3}$ in group 2 (failed IVF). The analysis revealed that the uterine volume tended to depend on whether the patient had given birth in the past. In group 1 there were $87.5 \%$ of females who had given birth before, and in group 2 such patients made $65.7 \%$. The uterine volume in such patients was over $58 \mathrm{~mm}^{3}$. No association between the uterine volume and the ovarian reserve or IVF success was established during the study $(p>0.05)$ (Table 2).

On average, the volume of the endometrium ranged from 3.5 to $13.9 \mathrm{~mm}^{3}$ in women who achieved pregnancy after IFV. In women whose IVF failed this parameter varied from 4 to $14 \mathrm{~mm}^{3}$. No significant differences $(p>0.05)$ in the endometrial volume were observed between the groups with different ovarian reserves or different IVF outcomes (Table 2).

This means that myometrial and subendometrial volumes have no significant prognostic value for IVF success regardless of the quality of patient's ovarian reserve.

In contrast, the data on the endometrial volume available in the literature demonstrate its strong correlation with IVF success. Unlike thickness (midline echo), the endometrial volume is recommended as a predictor of an IVF cycle outcome [12]. Our study shows that the volume of the endometrium was significantly larger in patients who achieved pregnancy, regardless of their ovarian reserve, than in those whose IVF failed ( $p=0.003$; see Table 2). The endometrial volume was 1.4

Table 1. Characteristics of female patients with different ovarian reserves and the IVF outcome

\begin{tabular}{|c|c|c|c|c|c|}
\hline & \multicolumn{2}{|c|}{$\begin{array}{l}\text { Successful IVF cycle } \\
\qquad(n=21)\end{array}$} & \multicolumn{2}{|c|}{$\begin{array}{l}\text { Failed IVF cycle } \\
\quad(n=35)\end{array}$} & \multirow{2}{*}{$\mathrm{p}$} \\
\hline & $\begin{array}{l}\text { Good ovarian reserve } \\
\qquad(n=13) p^{1}\end{array}$ & $\begin{array}{l}\text { Diminished ovarian reserve } \\
\qquad(\mathrm{n}=8) \mathrm{p}^{2}\end{array}$ & $\begin{array}{l}\text { Good ovarian reserve } \\
\qquad(n=23) p^{3}\end{array}$ & $\begin{array}{l}\text { Diminished ovarian reserve } \\
\qquad(\mathrm{n}=12) \mathrm{p}^{4}\end{array}$ & \\
\hline Age. years & $33.27 \pm 4.98$ & $35.45 \pm 2.98$ & $35.09 \pm 3.46$ & $37.02 \pm 2.87$ & - \\
\hline Body mass index & $24.36 \pm 1.98$ & $24.76 \pm 1.43$ & $25.02 \pm 1.17$ & $25.32 \pm 1.87$ & - \\
\hline History of infertility. years & $4.16 \pm 2.54$ & $5.26 \pm 3.54$ & $5.98 \pm 2.07$ & $5.41 \pm 3.07$ & - \\
\hline Primary sterility & $\begin{array}{c}3 \\
14.3 \%\end{array}$ & $\begin{array}{c}6 \\
28.6 \%\end{array}$ & $\begin{array}{c}5 \\
14.3 \%\end{array}$ & $\begin{array}{c}10 \\
28.6 \%\end{array}$ & - \\
\hline Secondary sterility & $\begin{array}{c}10 \\
47.6 \%\end{array}$ & $\begin{array}{c}2 \\
9.5 \%\end{array}$ & $\begin{array}{c}18 \\
51.4 \%\end{array}$ & $\begin{array}{c}2 \\
5.7 \%\end{array}$ & - \\
\hline $\begin{array}{l}\text { FSH levels. } \\
\mathrm{mlU} / \mathrm{ml}\end{array}$ & $6.8 \pm 1.56$ & $11.99 \pm 7.03$ & $7.18 \pm 1.79$ & $12.29 \pm 5.99$ & $\begin{array}{l}\mathrm{p}^{1} / \mathrm{p}^{2}=0.001^{\star} \\
\mathrm{p}^{3} / \mathrm{p}^{4}=0.002^{*}\end{array}$ \\
\hline $\begin{array}{l}\text { AMH levels. } \\
\mathrm{ng} / \mathrm{ml}\end{array}$ & $3.26 \pm 1.27$ & $0.61 \pm 0.42$ & $3.57 \pm 2.43$ & $0.65 \pm 0.37$ & $\begin{array}{l}p^{1} / p^{3}=0.021^{*} \\
p^{2} / p^{4}=0.001^{\star}\end{array}$ \\
\hline rFSH dose. IU & $2202.5 \pm 986.8$ & $1602.9 \pm 796.8$ & $2309.2 \pm 862.2$ & $1809.2 \pm 987.8$ & - \\
\hline $\begin{array}{l}\text { Endometrial thickness on } \\
\text { the day of ET. mm }\end{array}$ & $10.4 \pm 2.6$ & $10.60 \pm 1.94$ & $8.4 \pm 0.9$ & $8.31 \pm 1.28$ & $\begin{aligned} \mathrm{p}^{1} / \mathrm{p}^{3} & =0.05^{*} \\
\mathrm{p}^{2} / \mathrm{p}^{4} & =0.003^{*}\end{aligned}$ \\
\hline $\begin{array}{l}\text { Number of transferred } \\
\text { embryos }\end{array}$ & $1.49 \pm 0.21$ & $1.59 \pm 0.29$ & $1.76 \pm 0.68$ & $1.32 \pm 0.43$ & - \\
\hline Ovarian surgeries & $\begin{array}{c}1 \\
4.8 \%\end{array}$ & $\begin{array}{c}3 \\
14.9 \%\end{array}$ & $\begin{array}{c}5 \\
14.9 \%\end{array}$ & $\begin{array}{c}7 \\
40 \%\end{array}$ & - \\
\hline $\begin{array}{l}\text { Number of ovarian } \\
\text { pathologies in the patient's } \\
\text { medical history }\end{array}$ & $\begin{array}{c}4 \\
19.0 \%\end{array}$ & $\begin{array}{c}2 \\
9.5 \%\end{array}$ & $\begin{array}{c}9 \\
25.7 \%\end{array}$ & $\begin{array}{c}8 \\
22.9 \%\end{array}$ & - \\
\hline
\end{tabular}

Note: * - represents significant differences. 
Table 2. Volumes of the myometrium, subendometrium and endometrium measured by 3D power Doppler

\begin{tabular}{|c|c|c|c|c|c|}
\hline & \multicolumn{2}{|c|}{$\begin{array}{l}\text { Successful IVF cycle } \\
\qquad(\mathrm{n}=21)\end{array}$} & \multicolumn{2}{|c|}{$\begin{array}{l}\text { Failed IVF cycle } \\
\qquad(\mathrm{n}=35)\end{array}$} & \multirow[t]{2}{*}{$\mathrm{p}$} \\
\hline & $\begin{array}{l}\text { Good ovarian reserve } \\
\qquad \begin{array}{c}\left(\mathrm{mm}^{3}\right) \\
(\mathrm{n}=13) \\
\mathrm{p}^{1}\end{array}\end{array}$ & $\begin{array}{l}\text { Diminished ovarian reserve } \\
\qquad\left(\mathrm{mm}^{3}\right) \\
(\mathrm{n}=8) \\
\mathrm{p}^{2}\end{array}$ & $\begin{array}{l}\text { Good ovarian reserve } \\
\qquad \begin{array}{c}\left(\mathrm{mm}^{3}\right) \\
(\mathrm{n}=25) \\
\mathrm{p}^{3}\end{array}\end{array}$ & $\begin{array}{l}\text { Diminished ovarian reserve } \\
\qquad\left(\mathrm{mm}^{3}\right) \\
(\mathrm{n}=12) \\
\mathrm{p}^{4}\end{array}$ & \\
\hline Volume of myometrium & $49.4 \pm 5.01$ & $47.2 \pm 4.98$ & $49.2 \pm 3.67$ & $48.6 \pm 5.12$ & - \\
\hline Volume of subendometrium & $10.0 \pm 1.1$ & $9.8 \pm 0.8$ & $8.9 \pm 0.8$ & $8.7 \pm 0.7$ & - \\
\hline Volume of endometrium & $2.53 \pm 0.19$ & $1.38 \pm 0.31$ & $1.79 \pm 0.38$ & $0.82 \pm 0.25$ & $\begin{array}{l}\mathrm{p}^{1} / \mathrm{p}^{2}=0.004^{*} \\
\mathrm{p}^{3} / \mathrm{p}^{4}=0.008^{\star} \\
\mathrm{p}^{1 / \mathrm{p}^{3}}=0.05^{\star} \\
\mathrm{p}^{2} / \mathrm{p}^{4}=0.02^{*}\end{array}$ \\
\hline
\end{tabular}

Note: * — represents significant differences.

and 1.7 times bigger, respectively, in patients whose IVF was effective and ovarian reserve was good than in those whose IVF failed ( $p=0.004, p=0.008$; see Table 2$)$. This confirms that the volume of the endometrium can be used for predicting the success of IVF cycles.

The endometrial volume was relatively small on the day of embryo transfer in the patients who had undergone endometrial curettage in the past, in contrast to those who had not had a prior surgery. This was true for all patients regardless of their IVF outcome.

To predict the success of IVF cycles, we used 3D power Doppler ultrasonography which helps to measure the parameters of the low-velocity blood flow typical for the myometrium and endometrium. Some authors point out that 3D power Doppler is more effective for the imaging of blood vessels with low-velocity blood flow [11].

Histogram indices of myometrial and subendometrial blood flow presented in Table 3 were significantly higher in the patients who achieved pregnancy after ET. VI and VFI computed for the myometrium were 1.6 and 2.0 times higher, respectively, in the patients whose IVF was successful than in those whose IVF failed. A similar tendency was observed for the subendometrial region where $\mathrm{VI}$ and $\mathrm{VFI}$ were 2.6 and 2.5 times higher, respectively, in the patients whose IVF was successful than in those whose IVF failed.

In the patients with diminished ovarian reserve whose IVF was ineffective, the myometrial VI and VFI were 1.6 and 1.5 times lower, respectively, and the subendometrial VFI was 2.5 lower than in the females with normal ovarian reserve whose IVF was also ineffective $(p<0.05$; see Table 3$)$. This suggests poor uterine blood supply in the patients with diminished ovarian reserve.

In contrast, the patients who achieved pregnancy after IVF showed no differences in the blood flow indices, regardless of the ovarian reserve quality.

To compare the approaches to the assessment of the endometrial blood flow (the subendometrium excluded and included into the studied volume; see Fig.1), we used the ROCAUC analysis (Fig.2); it revealed no associations between the studied blood flow indices and the success of IVF (Fig. 2 A; AUC for $\mathrm{VI}$ was 0.49 , for $\mathrm{FI}, 0.50$, for $\mathrm{VFI}, 0.49$ ).

For the reconstructed images that included the $5-\mathrm{mm}$ shell around the basal layer (the subendometrium), an association was established between the studied blood flow indices and the outcome of IVF cycles (Fig. 2 B) (AUC for VI was 0.88, for $\mathrm{FI}, 0.66$; for VFI, 0.91).

Using the data obtained with 2D and 3D ultrasonography, we identified 3 major parameters that showed a reliable correlation with IVF success regardless of the patient's ovarian reserve: the volume of the endometrium, myometrial $\mathrm{VI}$ and subendometrial VFI. The prognostic value of these parameters was demonstrated using the ROC-curve (Fig. 3). For the endometrial volume sensitivity was $74.8 \%$; specificity $60.6 \%$; AUC 0.851; for the myometrial VI these values were $86.4 \%$, $69.4 \%$, and 0.857 , respectively, and for the subendometrial VFI they were $90.4 \%, 79.4 \%$ and 0.916 , respectively.

Table 3. Uterine hemodynamics in patients with different ovarian reserve and IVF outcomes

\begin{tabular}{|c|c|c|c|c|c|c|c|c|c|c|}
\hline \multirow{2}{*}{ Groups } & \multirow{2}{*}{$\begin{array}{l}\text { Effect/3D Doppler } \\
\text { parameters }\end{array}$} & \multicolumn{3}{|c|}{ Uterus } & \multicolumn{3}{|c|}{ Subendometrium } & \multicolumn{3}{|c|}{ Endometrium } \\
\hline & & VI & $\mathrm{FI}$ & VFI & VI & $\mathrm{FI}$ & VFI & VI & $\mathrm{FI}$ & VFI \\
\hline \multirow{2}{*}{ 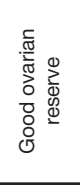 } & $\begin{array}{l}\text { Successful cycle } \\
\qquad(n=13) \\
p^{1}\end{array}$ & $11.41 \pm 2.19$ & $16.16 \pm 2.90$ & $1.77 \pm 0.35$ & $6.13 \pm 4.23$ & $10.0 \pm 1.17$ & $0.92 \pm 0.64$ & $3.41 \pm 2.82$ & $11.60 \pm 1.61$ & $0.32 \pm 0.33$ \\
\hline & $\begin{array}{l}\text { Failed cycle } \\
(n=25) \\
p^{2}\end{array}$ & $7.45 \pm 0.97$ & $12.75 \pm 1.68$ & $0.94 \pm 0.05$ & $3.19 \pm 2.57$ & $10.55 \pm 1.90$ & $0.25 \pm 0.15$ & $2.5 \pm 2.22$ & $11.38 \pm 2.76$ & $0.27 \pm 0.21$ \\
\hline \multirow{2}{*}{ 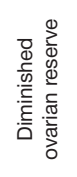 } & $\begin{array}{l}\text { Successful cycle } \\
(n=8) \\
p^{3}\end{array}$ & $10.56 \pm 2.57$ & $17.68 \pm 3.44$ & $1.92 \pm 0.75$ & $3.52 \pm 1.09$ & $11.12 \pm 1.03$ & $0.39 \pm 0.16$ & $2.40 \pm 1.84$ & $10.69 \pm 1.68$ & $0.22 \pm 0.20$ \\
\hline & $\begin{array}{l}\text { Failed cycle } \\
\qquad(\mathrm{n}=12) \\
\mathrm{p}^{4}\end{array}$ & $4.47 \pm 2.30$ & $14.05 \pm 3.32$ & $0.62 \pm 0.28$ & $1.23 \pm 1.27$ & $8.61 \pm 3.95$ & $0.10 \pm 0.08$ & $1.82 \pm 1.49$ & $11.17 \pm 2.16$ & $0.19 \pm 0.16$ \\
\hline \multicolumn{2}{|r|}{$\mathrm{p}$} & $\begin{array}{l}\mathrm{p}^{1} / \mathrm{p}^{2}=0.007^{\star \star} \\
\mathrm{p}^{3} / \mathrm{p}^{4}=0.003^{\star \star} \\
\mathrm{p}^{1 / \mathrm{p}^{3}}=0.62 \\
\mathrm{p}^{2} / \mathrm{p}^{4}=0.014^{\star}\end{array}$ & $\begin{array}{l}p^{1 / p^{2}}=0.06 \\
p^{3 / p^{4}}=0.35 \\
p^{1 / p^{3}}=0.52 \\
p^{2} / p^{4}=0.41\end{array}$ & $\begin{array}{l}\mathrm{p}^{1 / \mathrm{p}^{2}}=0.23 \\
\mathrm{p}^{3} / \mathrm{p}^{4}=0.009^{\star *} \\
\mathrm{p}^{1 / \mathrm{p}^{3}}=0.78 \\
\mathrm{p}^{2} / \mathrm{p}^{4}=0.011^{\star}\end{array}$ & $\begin{array}{l}\mathrm{p}^{1} / \mathrm{p}^{2}=0.24 \\
\mathrm{p}^{3} / \mathrm{p}^{4}=0.014^{\star} \\
\mathrm{p}^{1 / \mathrm{p}^{3}}=0.27 \\
\mathrm{p}^{2} / \mathrm{p}^{4}=0.12\end{array}$ & $\begin{array}{l}\mathrm{p}^{1 / \mathrm{p}^{2}}=0.58 \\
\mathrm{p}^{3 / \mathrm{p}^{4}}=0.18 \\
\mathrm{p}^{1 / \mathrm{p}^{3}}=0.19 \\
\mathrm{p}^{2} / \mathrm{p}^{4}=0.30\end{array}$ & $\begin{array}{l}\mathrm{p}^{1} / \mathrm{p}^{2}=0.013^{\star} \\
\mathrm{p}^{3} / \mathrm{p}^{4}=0.007^{\star \star} \\
\mathrm{p}^{1 /} / \mathrm{p}^{3}=0.12 \\
\mathrm{p}^{2} / \mathrm{p}^{4}=0.04^{\star}\end{array}$ & $\begin{array}{l}p^{1 / p^{2}}=0.34 \\
p^{3 / p^{4}}=0.82 \\
p^{1 / p^{3}}=0.21 \\
p^{2 / p^{4}}=0.41\end{array}$ & $\begin{array}{l}\mathrm{p}^{1 / p^{2}}=0.83 \\
\mathrm{p}^{3 / \mathrm{p}^{4}}=0.65 \\
\mathrm{p}^{1 / p^{3}}=0.37 \\
\mathrm{p}^{2 / p^{4}}=0.85\end{array}$ & $\begin{array}{l}\mathrm{p}^{1 / \mathrm{p}^{2}}=0.57 \\
\mathrm{p}^{3 / \mathrm{p}^{4}}=0.77 \\
\mathrm{p}^{1 / \mathrm{p}^{3}}=0.57 \\
\mathrm{p}^{2} / \mathrm{p}^{4}=0.32\end{array}$ \\
\hline
\end{tabular}

Note: * - difference significant at $p<0.05 ;{ }^{* *}$ - difference significant at $p<0.01$. 


\section{DISCUSSION}

The thickness of the endometrium (midline echo) was measured by $2 \mathrm{D}$ ultrasonography. There is no consensus in the literature on the minimal endometrial thickness necessary for achieving pregnancy. The majority of the researchers report failed IVF in patients with endometrial thickness less than $7 \mathrm{~mm}[7,13,14]$. However, there are reports of pregnancy in patients with 6-mm- or even 4-mm-thick endometrium [15]. Endometrial thickness over $14 \mathrm{~mm}$ is associated with a high risk of miscarriage [7].

Our study reveals that endometrial thickness measured by 2D ultrasonography in patients with different ovarian reserve correlates with the outcomes of IVF cycles. The differences were more significant $(p=0.003)$, though, for the patients with good ovarian reserve than for those with diminished ovarian reserve $(p=0.05)$. Some researchers have demonstrated

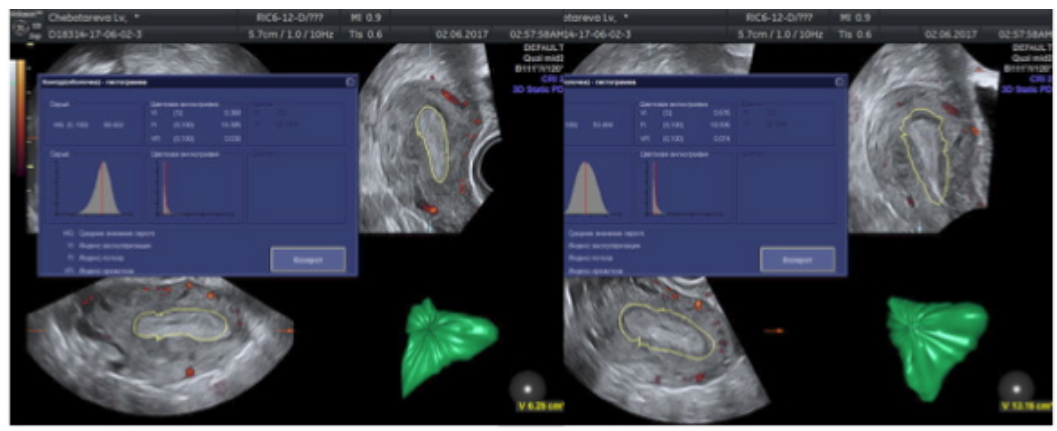

A Blood flow in the endometrium

B Blood flow in the subendometrium

Fig. 1. Blood flow assessment in the endometrium (the subendometrial region excluded and included)

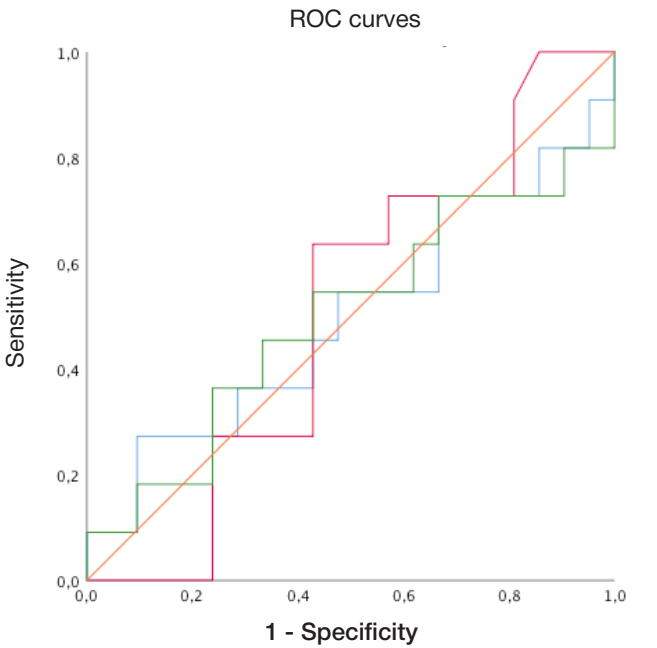

\author{
Curve constructed from \\ Endometrial VI \\ - Endometrial FI \\ - Endometrial FVI \\ - Baseline
}

A Blood flow in the endometrium

Diagonal segments generated by the associations

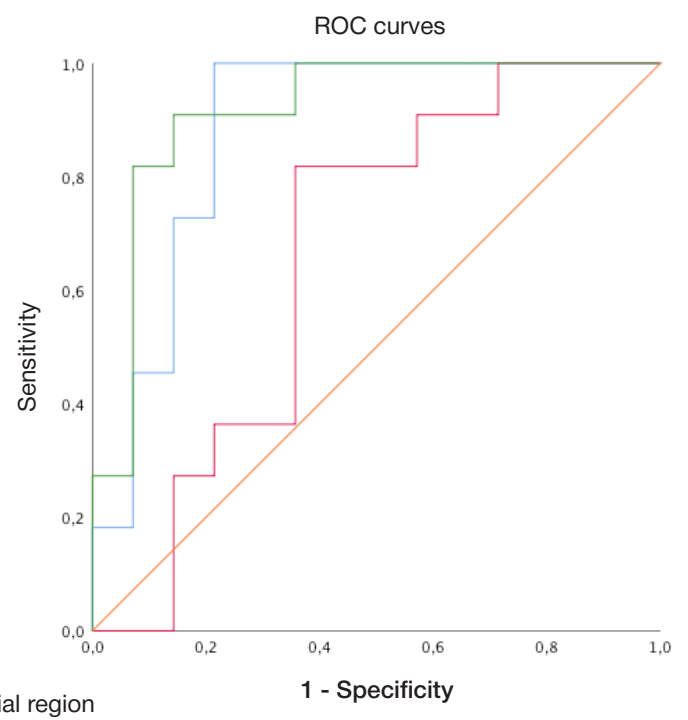

Curve constructed from

- Subendometrial VI

- Subendometrial FI

- Subendometrial VFI

- Baseline

B Blood flow in the subendometrial region

1 - Specificity

Fig. 2. ROC-analysis of the associations between IVF outcomes and the blood flow in the endometrium (A) and the subendometrial region (B) 


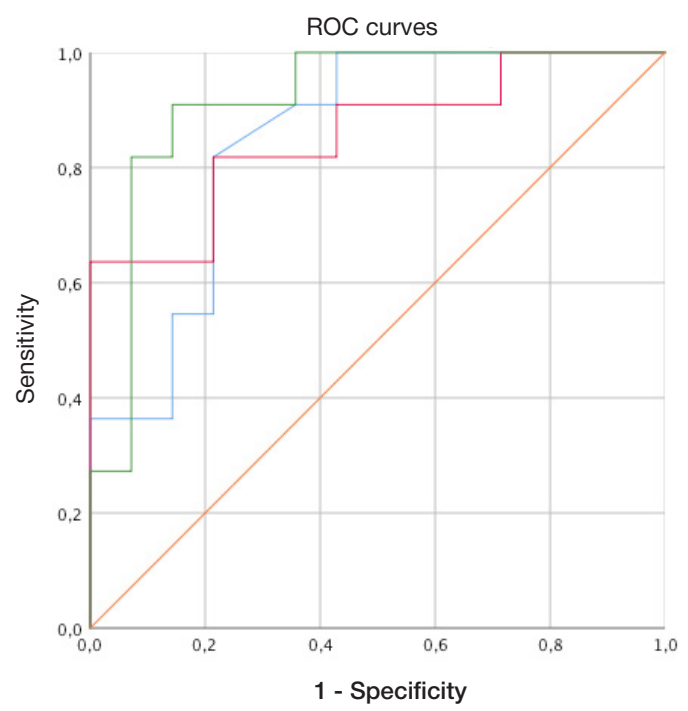

Diagonal segments generated by the associations

Fig. 3. ROC-analysis of the associations between IVF outcomes and the endometrial volume, myometrial VI and subendometrial VFI

the lack of associations between the success of IVF and the thickness of the endometrium [14]. It has been also reported that patients older than 40 tend to have thinner endometrium, which is a consequence of lower estradiol levels [12]. A few authors believe that endometrial thickness is a subjective parameter, so 3D sonography appears to be a more reliable tool for measuring the endometrial volume and establishing an association between this parameter and the success of IVF [9]. The use of 3D ultrasonography allowed us to reveal significant differences in the endometrial volume in the patients whose IVF outcomes were different $(p=0.05 ; p=0.02)$. The endometrial volumes were also significantly different in the patients who achieved pregnancy but had different ovarian reserves ( $p=0.004)$; however, no significant difference was observed between the patients with regard to their endometrial thickness.

Uterine blood flow plays an important role in the prediction of IVF outcomes. The meta-analysis of the literature has demonstrated that indices of subendometrial and endometrial blood flows can indirectly reflect endometrial receptivity [5]. It is known that blood is supplied to the endometrium mainly by spiral arteries which are a continuation of the basal arteries located in the subendometrium [11]. The subendometrial region should be included in the studied volume because the subendometrial blood flow indices show the intensity of blood flow in the arcuate artery and its radial branches.

Due to a high risk of injury to the endometrium, invasive techniques cannot be used on the day of embryo transfer for the assessment of endometrial receptivity. Non-invasive techniques are recommended instead. Ultrasonography of the myometrial and subendometrial blood flows has revealed significant differences between the patients regardless of the quality of their ovarian reserve in the myometrial IV $(p=0.007$ for the patients with normal ovarian reserve; $p=0.003$ for the patients with diminished ovarian reserve) and the subendometrial VFI ( $p=0.013$ for the patients with normal ovarian reserve and $\mathrm{p}=0.007$ for the patients with diminished ovarian reserve). The lowest values were observed in the patients with low ovarian reserve who failed to achieve pregnancy. It is believed that in patients with decreased ovarian reserve reduced blood flow indices result from the impaired growth of blood vessels in the functional endometrial layer due to the insufficient effect of estrogen during the proliferative stage [16].

Our findings are consistent with the results of the study [17] suggesting that estrogen content in the serum can be reliably associated with the intensity of the uterine blood flow during IVF cycles in patients who receive gonadotropins and gonadotropin-releasing hormone antagonists. It has been proved that hormone replacement therapy considerably improves the uterine blood flow (as and its indices measured by Doppler sonography) in patients with premature ovarian insufficiency [18].

Thus, our findings suggest that the use of 3D power Doppler ultrasonography on the day of embryo transfer can be an effective technique for the indirect assessment of endometrial receptivity, which is consistent with the data obtained by other researchers [5], and a good tool for predicting the outcome of an IVF cycle after embryo transfer.

Once we know myometrial and subendometrial blood flow characteristics, we can avoid useless embryo transfers. Patients with diminished ovarian reserve are recommended to undergo uterine flow examinations and therapies aimed at improving uterine perfusion (should there be any deviations from the norm) before starting IVF.

\section{CONCLUSIONS}

We have demonstrated that 3D power Doppler ultrasonography is a reliable method for the assessment of uterine perfusion on the day of embryo transfer in patients undergoing infertility treatment. Myometrial and subendometrial blood flow indices are better predictors of IVF success than characteristics of the endometrial blood flow which showed no correlation with the IVF outcomes in our study. Endometrial volume measured by 3D Doppler has a higher prognostic value than endometrial thickness measured by 2D ultrasound. Considering very low values of blood flow indices in patients with diminished ovarian reserve whose IVF was ineffective, we recommend 3D Doppler scans for such patients before embryo transfer. 
1. Anshina MB, Isakova EHV, Kalinina EAnat, Kalinina EAndr, Korsak VS, Krasnopolskaya KV i dr. Priemenie estrogenov v programmach WPT. Nachno-practicheskie rekomendacii. M.: Rossiyskaja associaacija reprodukcii sheloveka. 2015; 80 s.

2. Nazarenko TA, Krasnoposkaya KV. «Poor response.» Tactica vedenija pacientok so snijennoy reacciej a stimuljaciju gonadotropinami v programmach EKO. M. : MEDpress-inform, 2013. $80 \mathrm{~s}$.

3. Korsak VS, Smirnova AA, Shurygina OV. VRT v Rossii. Otchet za 2013 g. Problemy reprodukcii. 2015; 21 (6): 17-19

4. Mishra W, Agarwal R, Sharma U, Aggarwal R, Choudhary S, Bandwal P. Endometrial and Subendometrial Vascularity by Three-Dimensional (3D) Power Doppler and Its Correlation with Pregnancy Outcome in Frozen Embryo Transfer (FET) Cycles. J of Obstetrics and Gynaecology of India. 2016; 66 (Suppl 1): $521-$ 527. DOI: 10.1007/s13224-016-0871-5.

5. Jianing Wang, Fei Xia, Ying Zhou, Xuedong Wei, Yanyan Zhuang, Yingxue Huang. Association Between Endometrial/ Subendometrial Vasculature and Embryo Transfer Outcome: A Meta-analysis and Subgroup Analysis. J Ultrasound Med. 2018 Jan; 37 (1): 149-163. DOI: 10.1002/jum.14319. Epub 2017 Jul 17.

6. Lecce G, Meduri G, Ancelin M. Presence of estrogen receptor bin the human endometrium through the cycle: expression inglandular, stromal, and vascular cells. J Clin Endocrinol Metab. 2001; 86: 1379-86.

7. Amir W, Micha B, Ariel H, Liat LG, Jehoshua D, Adrian S. Predicting factors for endometrial thickness during treatment with assisted reproductive technology. Fertil Steril 2007; 87 (4): 799-804.

8. Kalmantis K, Loutradis D, Lymperopoulos E, Beretsos P, Bletsa R, Antsaklis A. Three Dimensional Power Doppler evaluation of human endometrium after administration of oxytocine receptor antagonist (OTRa) in an IVF program., Arch Gynecol Obstet. 2012 Jan; 285 (1): 265-70. DOI: 10.1007/s00404-011-2019-2. Epub 2011 Aug 7.

9. Prasad S, Goyal R, Kumar Y, et al. The Relationship Between Uterine Artery two-dimensional Color Doppler Measurement and
Pregnancy Outcome: A Prospective Observational Study. Journal of Reproduction \& Infertility. 2017; 18 (2): 251-6.

10. Krylova YuS, Kvetnoj IM, Ajlamazyan EK. Receptivnost' endometrija: moleculjarnye mechanizmy eguljacii implantacii. J akusherstva i jenskich boleznej. 2013; 62 (2): 63-74. DOI: http:// dx.doi.org/10.17816/JOWD62263-74

11. Ozerskaja IA. Atlas ginekologischeskoj ul'trazvukovoj normy. M.: Vidar-M; 2010. 225 s.

12. Ari Kim, Hyuk Jung, Won June Choi, Sung Nam Hong, Heung Yeol $\mathrm{Kim}$. Detection of endometrial and subendometrial vasculature on the day of embryo transfer and prediction of pregnancy during fresh in vitro fertilization cycles Taiwanese. Journal of Obstetrics \& Gynecology. 2014; 53 (3): 360-5.

13. Krasnopol'skaya KV, Nazarenko TA, Sesina NI, Ershova IYu, Aleksandrova VR. Rezul'taty programmy EKO s donorskimi oocitami u pacientok s ul'trazvukovymi prinakami "tonkogo" endometrija. Medicinskij alfavit. M.: Al'famed. 2017; 1 (12) (309) : 34-8.

14. Kasius A, Smit JG, Torrance HL et al. Endometrial thickness and pregnancy rates after IVF: a systematic review and meta-analysis. Hum Reprod Update. 2014; 20 (4): 530-41.

15. Weiss NS, van Vliet MN, Limpens J, Hompes PGA et al. Endometrial thickness in women undergoing IUI with ovarian stimulation. How thick is too thin? A systematic review and metaanalysis. Hum Reprod Update. 2017; 32 (5): 1009-18.

16. Jayaprakasan K, Hopkisson JF, Campbell BK, Clewes J, Johnson $I R$, Raine-Fenning NJ. Quantification of the effect of pituitary down-regulation on 3D ultrasound predictors of ovarian response. Human Reproduction. 2008; 23 (7): 1538-44.

17. Bassil S. Changes in endometrial thickness, width, length and pattern in predicting pregnancy outcome during ovarian stimulation in in vitro fertilization. Ultrasound Obstet Gynecol. 2001 Sep; 18 (3): 258-63.

18. Mayra PR, Rosalina VL, López G, Iruretagoyena J, Magness R. Regulation of uterine blood flow. I. Functions of estrogen and estrogen receptor $\alpha / \beta$ in the uterine vascular endothelium during pregnancy. Rev Chil Obstet Ginecol. 2014; 79 (2): 129-39.

\section{Литература}

1. Аншина М. Б., Исакова Э. В., Калинина Е. Анат., Калинина Е Андр., Корсак В. С., Краснопольская К. В. и др. Применение эстрогенов в программах ВРТ. Научно-практические рекомендации. М.: Российская ассоциация репродукции человека. 2015, 80 c

2. Назаренко Т. А, Краснопольская К. В. «Бедный ответ». Тактика ведения пациенток со сниженной реакцией на стимуляцию гонадотропинами в программах ЭКО. М. МЕДпресс-инсрорм; 2013, 80 с.

3. Корсак В. С., Смирнова А. А., Шурыгина О. В. ВРТ в России Отчет за 2013 г. Проблемы репродукции. 2015; 21 (6): 17-19.

4. Mishra W, Agarwal R, Sharma U, Aggarwal R, Choudhary S, Bandwal P. Endometrial and Subendometrial Vascularity by Three-Dimensional (3D) Power Doppler and Its Correlation with Pregnancy Outcome in Frozen Embryo Transfer (FET) Cycles. J of Obstetrics and Gynaecology of India. 2016; 66 (Suppl 1): 521527. DOI: 10.1007/s13224-016-0871-5.

5. Jianing Wang, Fei Xia, Ying Zhou, Xuedong Wei, Yanyan Zhuang, Yingxue Huang. Association Between Endometrial/ Subendometrial Vasculature and Embryo Transfer Outcome: A Meta-analysis and Subgroup Analysis. J Ultrasound Med. 2018 Jan; 37 (1): 149-163. DOI: 10.1002/jum.14319. Epub 2017 Jul 17

6. Lecce G, Meduri G, Ancelin M. Presence of estrogen receptor bin the human endometrium through the cycle: expression inglandular, stromal, and vascular cells // J Clin Endocrinol. Metab. 2001; 86: 1379-86.

7. Amir W, Micha B, Ariel H, Liat LG, Jehoshua D, Adrian S. Predicting factors for endometrial thickness during treatment with assisted reproductive technology. Fertil Steril 2007; 87 (4): 799-804.

8. Kalmantis K, Loutradis D, Lymperopoulos E, Beretsos P, Bletsa R, Antsaklis A. Three Dimensional Power Doppler evaluation of human endometrium after administration of oxytocine receptor antagonist (OTRa ) in an IVF program., Arch Gynecol Obstet. 2012 Jan; 285 (1): 265-70. DOI: 10.1007/s00404-011-2019-2. Epub 2011 Aug 7.

9. Prasad S, Goyal R, Kumar Y, et al. The Relationship Between Uterine Artery two-dimensional Color Doppler Measurement and Pregnancy Outcome: A Prospective Observational Study. Journal of Reproduction \& Infertility. 2017; 18 (2): 251-6.

10. Крылова Ю. С, Кветной И. М., Айламазян Э. К. Рецептивность эндометрия: молекулярные механизмы регуляции имплантации. Журнал акушерства и женских болезней. 2013; 62 (2): 63-74. DOl: http://dx.doi.org/10.17816/JOWD62263-74.

11. Озерская И. А. Атлас гинекологической ультразвуковой нормы. М.: Видар-М; 2010. 225 с.

12. Ari Kim, Hyuk Jung, Won June Choi, Sung Nam Hong, Heung Yeol Kim. Detection of endometrial and subendometrial vasculature on the day of embryo transfer and prediction of pregnancy during fresh in vitro fertilization cycles Taiwanese. Journal of Obstetrics \& Gynecology. 2014; 53 (3): 360-5.

13. Краснопольская К. В., Назаренко Т. А., Сесина Н. И., Ершова И. Ю., Александрова В. Р. Результаты программ ЭКО с донорскими ооцитами у пациенток с ультразвуковыми признаками “тонкого" эндометрия. Медицинский алфавит. М.: Альфмед. 2017; 1 (12) (309) : 34-8. 
14. Kasius A, Smit JG, Torrance HL et al. Endometrial thickness and pregnancy rates after IVF: a systematic review and meta-analysis. Hum Reprod Update. 2014; 20 (4): 530-41.

15. Weiss NS, van Vliet MN, Limpens J, Hompes PGA et al. Endometrial thickness in women undergoing IUI with ovarian stimulation. How thick is too thin? A systematic review and metaanalysis. Hum Reprod Update. 2017; 32 (5): 1009-18.

16. Jayaprakasan K, Hopkisson JF, Campbell BK, Clewes J, Johnson $I R$, Raine-Fenning NJ. Quantification of the effect of pituitary down-regulation on 3D ultrasound predictors of ovarian response.
Human Reproduction. 2008; 23 (7): 1538-44.

17. Bassil S. Changes in endometrial thickness, width, length and pattern in predicting pregnancy outcome during ovarian stimulation in in vitro fertilization. Ultrasound Obstet Gynecol. 2001 Sep; 18 (3): 258-63.

18. Mayra PR, Rosalina VL, López G, Iruretagoyena J, Magness R. Regulation of uterine blood flow. I. Functions of estrogen and estrogen receptor $\alpha / \beta$ in the uterine vascular endothelium during pregnancy. Rev Chil Obstet Ginecol. 2014; 79 (2): 129-39. 